\title{
Household Level Gender Roles and Empowerment in a Coffee Value Chain in Gomma and Limmu Kossa Districts of Jimma Zone, Ethiopia
}

\author{
Bizualem Assefa Gashaw \\ Department of Agribusiness and Value Chain Management, Wolkite University, Wolkite, Ethiopia
}

\section{Email address:}

abizualem@gmail.com

\section{To cite this article:}

Bizualem Assefa Gashaw. Household Level Gender Roles and Empowerment in a Coffee Value Chain in Gomma and Limmu Kossa Districts of Jimma Zone, Ethiopia. Journal of Business and Economic Development. Vol. 3, No. 3, 2018, pp. 62-67.

doi: $10.11648 /$ j.jbed.20180303.11

Received: September 20, 2018; Accepted: October 8, 2018; Published: November 14, 2018

\begin{abstract}
Gender is the socially and culturally constructed differences associated with being a man or a woman. For providing the opportunity of substantial economic and income growth in a country, the growing integration of gender issues in a value chain has part. The objective of this study was to analyse intra-household gender roles and empowerment of men and women with in the household and suggesting strategies for addressing gender based constraints of farmers in a coffee value chain. Two-stage stratified and random sampling procedures were employed; and a total of 120 male headed smallholder farmers (where both men and women are present together) from six kebeles were used for intra-household gender analysis. Data were collected from both secondary and primary sources through semi-structured questionnaire, checklists, and focus group discussion. Descriptive gender analysis by Moser gender framework was used to analyse data. The result of gender analysis revealed that women's and men's role for coffee business in a household was divided by task. Women undertaken mostly the processing, seedling rising and unpaid community activities as an extension of their reproductive role and are normally unpaid and carried out in their free time. On the other hand, men tend to be associated more with production and marketing roles than in postharvest handling and processing activities. However, it is examined that unlike women's overall participation in a value chain was highly acknowledged, they still tend to be confined to a relatively less access to and control over resources and benefits earned from coffee business. Therefore, gender inclusive value chain strategies paying attention on women's empowerment and ensuring gender equality leaving women no worse off were recommended.
\end{abstract}

Keywords: Gender Analysis, Gender Role, Empowerment, Gender Based Constraint, Moser Gender Framework

\section{Introduction}

Agriculture remains to be the main stay of Ethiopian economy contributing about $47 \%$ of GDP and providing employment to more than $80 \%$ of the rural population [1]. Coffee is the major cash crop and, being a cornerstone in the export economy of the country, is source of foreign currency for Ethiopia [2]. Furthermore, it is estimated that between 7.5 and 8 million households depend on coffee for a considerable share of their income, and provides jobs for many more people in coffee-related activities of processing, transporting or marketing along the value chain [3]. Value chain is to mean the entire range of activities required to bring a product or service from the initial input-supply stage (conception) through the different phases of production (involving a combination of physical transformation and the input of various producer services), delivery to final consumers, and final disposal after use [4]

Women play a very important role in the agricultural value-chains in Ethiopia, starting from production through to value addition stages and marketing of the agricultural products. Yet, despite their important role in agricultural production and marketing, women's engagement in agricultural livelihoods does not always translate into increased income or improved decision-making capacity for women [5]. They primarily remain invisible in the work they 
do in value chains, yet contribute enormously to its output and value. Gender issues fundamentally shape the totality of production, distribution, and consumption within an economy but gender issues have often been overlooked in value chain development. From production to processing to disposal, 'gendered patterns' of behaviour condition men's and women's jobs and tasks, the distribution of resources and benefits derived from income- generating activities in the chain, and the efficiency and competitiveness of value chains in the global market.

For providing the opportunity of substantial economic and income growth for participants from the commodity under consideration, the growing integration of value chain approach in the global economy has part [6]. Organization of agriculture along the value-chain framework has been conceived as one of the strategies to bring more efficiency in the agricultural sector [7]. However, often interventions in value chain development will adversely affect women and men's respective shares of value added differently. It is due to the case that women may be excluded from gaining higher incomes in value chains [6]. This represents a missed opportunity as it prevents women farmers from achieving higher productivity. Hence, gender based value chain interventions require gender-sensitive value chain diagnostics/analysis prevailing dynamics on men and women. One way of doing this is to disaggregate impacts along gender lines, and see how men and women are affected with regard to income, employment and empowerment.

More specifically, according to the preliminary survey in the study districts, women in a given household participated mostly in processing and seedling rising while men involve in cultivation, loading and unloading, and transporting of coffee. Men have the power to control and administer on benefits the income generated from coffee while that of their wife in the household was negligible. While this disparity of farmer level gender roles and empowerment in coffee value chain is widely known in the area, no gender inclusive coffee value chain research was conducted there yet. The study in [8] conducted impact of pre and postharvest processing practices on the quality of both wet and dry processed coffee and its related problems in Jimma zone addressed nothing about the gender roles, while whom to target in pre and post-harvest value adding activities and improving quality of coffee in the value chain is the major issue. Therefore, conducting such a study on farmer level gender disaggregated analysis of roles, access to and control over resources and benefits of smallholder farmers is very important for designing gender based value chain development interventions and addressing gender issues (gender based constraints) in agricultural value chains.

\section{Methodology}

\subsection{Description of the Study Area}

Jimma zone is located in the South-Western part of Ethiopia between Latitude 60 and 9o North and Longitude $34 \mathrm{o}$ and $38 \mathrm{o}$ East, and between altitude ranges of 880 to 3340 meters above sea level [9]. The Zone is one of the coffee growing zones in the Oromia Regional State, Ethiopia which has a total area of 1.1 million hectares of land. Currently, the total area of land covered by coffee in the zone is about 0.1 million hectares, which includes small-scale farmers' holdings as well as state and private owned plantations. Jimma zone covers a total of $21 \%$ of the export share of the country and $43 \%$ of the export share of the Oromia Region [10]. There are favourable climatic conditions, variety of local coffee types for quality improvement and long history of its production in the Zone. In Jimma zone, coffee is produced in the eight districts namely, Gomma, Manna, Gera, Limmu Kossa, Limmu Seka, Seka Chokorsa, Kersa and Dedo, which serves as a major means of cash income for the livelihood of coffee farming families [10]. From among Limmu-Kossa and Gomma districts were selected.

Limmu-Kossa district is geographically located between $7050^{\prime}$ to $8036^{\prime}$ North and $36044^{\prime}$ to 370 29' East [9]. The total surface area of the district is $1355 \mathrm{~km}^{2}$. Agro-climatic condition of the district comprises of highland (25\%), midland $(65 \%)$ and lowland $(10 \%)$ with annual rain fall varying between 1200 to $2000 \mathrm{~mm}$ and altitude ranging between 1450 to 1950 masl while annual temperature is $10^{\circ} \mathrm{C}$ to $25^{\circ} \mathrm{C}$. The total population of the district is 187,815 out of which $50.5 \%$ are male. There are about 29,138 households (92.3\% male-headed) living in 40 kebeles and 3 towns (Limmu Genet, administrative center of district, Ambuye, and Babu). The average land holding size per house hold is 2.39 hectare out of which $24.6 \%$ is covered with annual crops.

Gomma is one of the known coffee growing districts of Jimma Zone. It is located $397 \mathrm{~km}$ Southwest of Addis Ababa and about $50 \mathrm{~km}$ west of Jimma town [9]. Its area is 1,230.2 $\mathrm{km}^{2}$. The annual rainfall varies between $800-2000 \mathrm{~mm}$, while the mean minimum and maximum annual temperatures of the district vary between $7^{\circ} \mathrm{C}-12^{\circ} \mathrm{C}$ and $25^{\circ} \mathrm{C}-30^{\circ} \mathrm{C}$, respectively [11]. Based on 15 years weather data obtained from Gomma district, the average annual rainfall is $1524 \mathrm{~mm}$. Altitudinal range of the district is between 1387-2870 masl. The three dominant soil types in the district are Eutric Vertisols, Humic Alfisols and Humic Nitosols. Nitosols are the most abundant covering about $90 \%$ of the district, which is dark reddish brown in colour, slightly acidic and suitable for coffee production. Agro-ecologically, this district is divided into highland $(8 \%)$, midland $(88 \%)$, and lowland $(4 \%)$. 


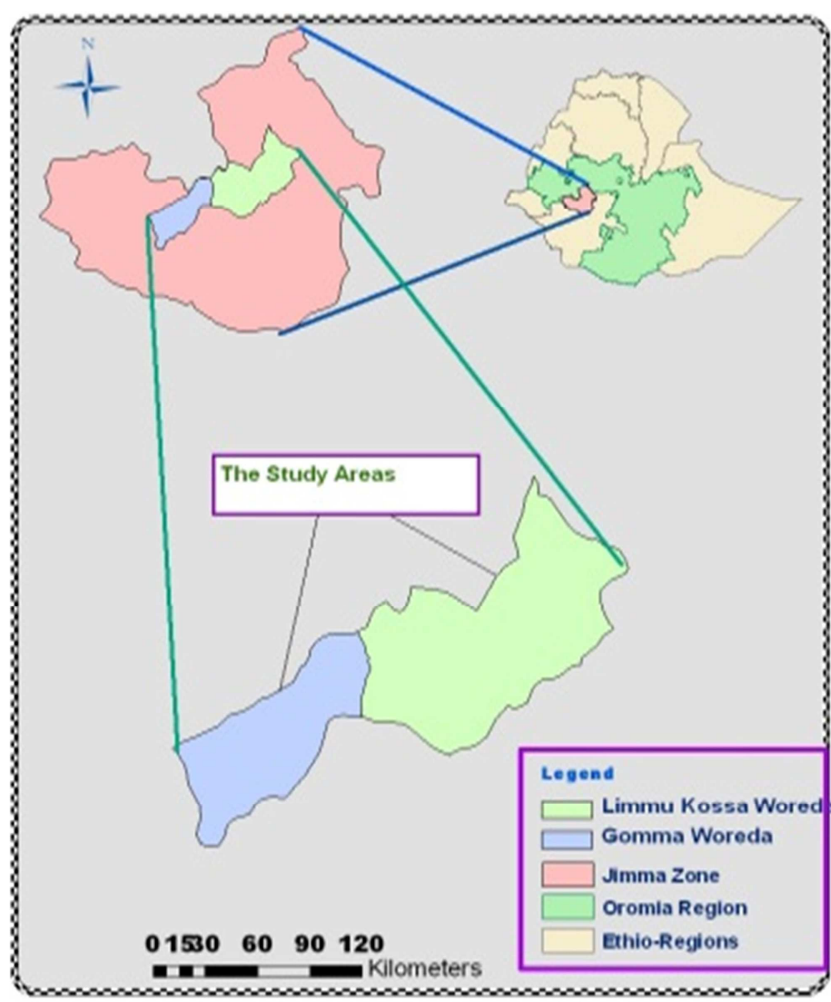

Source: Adopted and manipulated from Ethiopian map

Figure 1. Map of the study area

\subsection{Sampling Techniques and Sample Size Determination}

Two-stage stratified and random sampling techniques were employed for the study. Production potential of kebeles was important criteria to stratify kebeles for deriving representative sample kebeles. However, since it was difficult to get the actual volume of coffee production in each kebeles, agro-ecology was an alternative and best proxy for production potential in the study area. Thus, in the first stage, kebeles in the two districts were stratified into three by their agro-ecology as lowland, midland and highland. The lowland agro-ecology covers less than $10 \%$ in both districts while the highland agro-ecology covers only $8 \%$ in Gomma district. Accordingly, kebeles were sampled randomly and proportionately from midland and highland category in Limmu-Kossa district and from midland category in Gomma district. After screening out non- producing kebeles, proportionately four kebeles from Limmu-Kossa district (three from midland and one from highland) and two midland kebeles from Gomma district were randomly selected to obtain a total of six sample kebeles.

In the second stage, to consider the target populations (to avoid probability of including non-producers of coffee in the sample), only list of coffee farmers from sample kebeles were considered. Then, based on the number of coffee farmers available, proportional size of sample coffee farmers were selected from each sample kebeles using simple random sampling technique. Following the above sampling procedure, a total of 152 sample farmers were selected using [12] sample size determination formula. However, from the total of 152 smallholder farmers sampled, it was 120 $(78.95 \%)$ who are male headed households (where both men and women are presented), whereas 11 (7.24\%) were male headed household but only men are present in the home and the remaining $21(13.81 \%)$ were female headed households (where only women are present). Thus, it was based on the 120 male headed households that the intra-household gender analysis was done.

\subsection{Data Types, Sources, and Method of Data Collection}

The data, both quantitative and qualitative type, of this study were collected mainly from primary source through questionnaire, checklist, and group discussion. Secondary sources were also visited to collect some additional data. Semi-structured questionnaire was used for the data collection from smallholder farmers through trained enumerators. Qualitative data about business practices and transactions and the patterns and socio-economic activities of the farmers in the study areas were gathered informally through direct observation of the study areas and informal discussions with key informants like DAs, agriculture sector offices, administrators, and ethnic leaders. On the other hand, secondary data of both qualitative and quantitative such as agricultural inputs supplied and consumed, physical characteristics, population size etc. were gathered through thorough reviewing and examination of reports as well as records of published and unpublished documents.

\subsection{Method of Data Analysis}

Gender analysis was employed in collecting and analysing sex-disaggregated data and other qualitative and quantitative information on gender issues, including access to and control over assets (tangible and intangible), as well as beliefs, practices, and legal frameworks. It is all about identifying gender roles, understanding culture, expressed in the construction of gender identities and inequalities, and what that means in practical terms. It aims to uncover the dynamics of gender differences across a variety of issues. These include gender issues with respect to social relations (how 'male' and 'female' are defined in the given context; their normative roles, duties, responsibilities); activities (gender division of labour in productive and reproductive work within the household and the community; reproductive, productive, community managing and community politics roles); access and control over resources, services, institutions of decision-making and networks of power and authority; and needs, the distinct needs of men and women, both practical (i.e. given current roles, without challenging society) and strategic (i.e. needs which, if met, would change their position in society).

Much of the findings in this paper were thus drawn from this source. It begins with an organizing framework for undertaking a gender analysis to capture issues facing women producers at farmer level in value chains.1 Gender analysis

1 The analysis is focused on roles and empowerments of men and women with in a household (intra-household analysis) at the farmer level in value chain 
frameworks are tools to better understand the realities of the women and men whose lives are impacted by planned development. From these broad gender issues, gender based division of labour with in the household and access and/or control over resources/inputs and benefit obtained from participating in the coffee value chain were analysed in depth. Among other alternative frameworks, Moser framework (gender planning) was employed to frame the analysis. It takes the view that gender planning, unlike other mainstream planning, is "both technical and political in nature. It involves transformative processes and it characterizes planning as a "debate." Tools that the framework incorporated are identification of gender roles /triple role, gender needs assessment, disaggregating control of resources and decision and balancing of roles.

Tool 1 Gender roles identification/triple role: This tool includes making visible the gender division of labor. It was carried out by mapping all the activities of men and women (including girls and boys) in the household over a twenty four hour period. A triple role (productive, reproductive and community management roles) were identified.

Productive work: This is work that produces goods and services for consumption by the household or for income and is performed by both men and women.

Reproductive work: This work involved the bearing and rearing of children and all the tasks associated with domestic work and the maintenance of all household members. These tasks include cooking, washing clothes, cleaning, collecting water and fuel, caring for the sick and elderly.

Community roles: This includes community activities like provisioning and maintenance of resources which are used by everyone, such as water, healthcare, and education. It also includes politics at the community level.

Tool 2 Gender needs assessment: Moser developed this tool from the concept of women's gender interests which was first developed by Maxine Molyneux in 1984. Women's needs differ from men's needs. A distinction is made between practical gender needs and strategic gender interests/needs. Practical gender needs are those that women and men identified easily as they often relate to living conditions, whereas strategic gender needs are those that women themselves identify as due to their subordinate position to men in their society. They relate to issues of power and control, and to exploitation under the sexual division of labor. They are not as easily identified by women themselves as their practical needs; therefore, they may need specific opportunities to do so.

Practical and strategic gender interests/needs should not be seen as entirely distinct and separate, but rather as a continuum. By consulting women on their practical gender needs, entry points to address gender inequalities in the longer term (strategic gender interests/needs) can be created.

Tool 3 Disaggregating control of resources and decisionmaking: This tool was used to find out who has control over resources and decisions about the use of these resources within a household and how they are made (intra- household resource allocation and power of decision making).
Tool 4 Balancing of Roles: This relates to how women manage the balance between their productive, reproductive and community tasks. It asks as to which a planned value chain development intervention will balance a women's workload in one role with consequences for her other roles.

\section{Results and Discussion}

From a value chain viewpoint it makes sense to look into different roles and tasks of men and women in value chains and use a gender lens while identifying and addressing bottlenecks for value chain development. This is very crucial in recommending upgrading strategies, technology distribution, and other business opportunities. In this study, farm level gender analysis focusing on roles/task divisions, access to, and control over resources and/or benefits with in a household were given an emphasis and assessed exhaustively.

All the 120 sample farmers reported that women's and men's role in coffee business were divided by task and responsibilities in a household. The survey and FGD result revealed that women played very crucial role in coffee value addition at the farm level, but invisible. Mostly women are participated in seedling rising and processing while men involved in cultivation, loading, unloading, and transporting of coffee. As can be seen from the Table 1 below, the share of women's role $(42.3 \%)$ in post-harvest handling and processing was high compared to men. Men tend to be more associated with production and market roles than in postharvest handling and processing activities. Compared to men's production role (42.4\%), which however usually assumed as much more than women; there was not that much significance difference between men and women, in that women played $40.1 \%$ of production role besides high burdens of reproductive, domestic production and community role.

The result of survey revealed that women contributed $51.6 \%$ of reproductive role while it was only $12.9 \%$ for that of men. It was because women were generally expected to fulfill the reproductive responsibilities of bearing and rearing of children, caring for family members, and household management tasks, as well as home based production. Works in this category where women always involved were tasks associated with domestic work and the maintenance of all household members. These include cooking, washing clothes, cleaning, collecting water and fuel, caring for the sick and elderly.

With regard to community responsibilities, the role of women accounts $44.5 \%$ of the total household responsibility. This includes community activities like provisioning and maintenance of public resources such as water, healthcare, and education. These activities are undertaken as an extension of their reproductive role and are normally unpaid and carried out in their free time. In contrast it was mainly men who are involved in politics at the community level. This work may be paid or unpaid but can increase men's status and empowerment in the community, unlike women. 
Table 1. Gender disaggregated roles and responsibilities of farmers with in a household.

\begin{tabular}{|c|c|c|c|c|}
\hline \multicolumn{5}{|l|}{ Gender activity profile (\%) } \\
\hline Activities & Women & Men & Girls & Boys \\
\hline Production & 40.1 & 42.4 & 5.4 & 12.1 \\
\hline -Land preparation and cultivation & 21.6 & 65 & 2 & 11.4 \\
\hline -Coffee seedling rising & 48.5 & 38.5 & 5 & 8 \\
\hline -Manure/compost application & 34.7 & 36.4 & 10.3 & 18.6 \\
\hline -Mulching & 45 & 35 & 5 & 15 \\
\hline -Picking & 50.7 & 37.2 & 4.9 & 7.2 \\
\hline Processing & 42.3 & 38.7 & 8.3 & 10.7 \\
\hline -Cleaning/sorting & 72.5 & 10 & 10.5 & 7 \\
\hline -Transporting to home & 18.7 & 39.3 & 17 & 25 \\
\hline -Grading & 45.5 & 51 & 1.5 & 2 \\
\hline -Drying and de-hulling & 70 & 13 & 14.5 & 2.5 \\
\hline -Packing & 30.9 & 50 & 5.1 & 14 \\
\hline -Storing & 26.8 & 55 & 2.6 & 15.6 \\
\hline -Cleaning and caring the store & 63 & 13 & 14 & 10 \\
\hline -Loading/Unloading & 11 & 78.5 & 1.1 & 9.4 \\
\hline Marketing & 26.1 & 64.1 & 3.2 & 6.6 \\
\hline -Market searching & 13.5 & 82.3 & 0.5 & 3.7 \\
\hline -Transport to market & 25 & 58 & 7 & 10 \\
\hline -Selling in market & 27 & 65 & 2 & 6 \\
\hline Reproductive role & 51.55 & 12.85 & 21.85 & 13.75 \\
\hline -Food preparation & 61.1 & 5.4 & 27 & 6.5 \\
\hline -Fuel preparation & 38.6 & 24 & 22.4 & 15 \\
\hline -Water fetching & 50. & 7 & 18 & 25 \\
\hline -Bearing and rearing of children & 56.5 & 15 & 20 & 8.5 \\
\hline Community role & 44.5 & 40 & 5.3 & 10.2 \\
\hline $\begin{array}{l}\text {-Cooperation during wedding, } \\
\text { sorrow }\end{array}$ & 60 & 30 & 5 & 5 \\
\hline -Environmental protection & 28 & 55 & 6 & 11 \\
\hline -Soil and water conservation & 26.7 & 55 & 5.3 & 13 \\
\hline $\begin{array}{l}\text {-Maintenances of water, health } \\
\text { care, school }\end{array}$ & 63.2 & 19.8 & 5 & 12 \\
\hline Politics and meeting participation & 15.6 & 70.8 & 5.4 & 8.2 \\
\hline
\end{tabular}

Source: Own computation, 2015

Farmers with in a household were also assessed on their access to and control over resource/benefit they had in a household. Though the importance of women in the coffee business was remarkable, the power they had to access and control over the resources and benefits were less than that of their counterpart, men. In aggregate, the shares of men in accessing and controlling resources were $61.1 \%$ and $69 \%$ respectively. The corresponding figures for women were $38.9 \%$ and $31 \%$. From these figures one can understand that men's control over resources and benefits is more than what they access on, it is because men had a control over not only on his access but also on women's access. For instance men and women had equally and legally acknowledgeable access on land title/ownership in principle, but it was seen from the study that relatively men had control over the land. In both study districts, it has been customary that not only men but also women consider land is always associated to men.

Although women's overall participation in a coffee enterprise being highly acknowledged, they tend to be confined to a relatively less access to and control over the benefit earned from the coffee business. Men had relatively substantial control over income generated from coffee. The result of the study indicated that women had relatively lower access $(43 \%)$ to and control $(20 \%)$ over the benefit earned from coffee business. On top of this, due to religious and socio-economic factors men were not voluntary to send their wife to income generating works outside the home.

Furthermore, although, women provided significant contribution in production and processing activities, they couldn't join institutions (cooperatives and other social institutions like Idir, Iquib) on their name unless on their husband name, and, therefore, were less likely to get the opportunity of accessing leadership role, engaging in information/meeting, trainings, extension services there by decreasing their management function and empowerment in the coffee value chain. In all male-headed sample farmers, for instance, cooperative membership and then participation in it was known by the men only.

The study, on the other hand, revealed that power imbalance between men and women was perpetuated by the situation where men commonly enjoyed representation to access extension, training services and leadership power that build their capacity in management and administration. As depicted in Table 2, women's share of responsibilities and representations over key issues of the household such as access to markets and negotiation of better coffee prices is very minimal. Women's access to extension service, training and leadership were $26.6 \%, 22.5 \%$ and $35.8 \%$ respectively. The corresponding figures for control over these resources were $16.6 \%, 19 \%$ and $31 \%$. This ignorance or under valuing of women's productive role in coffee value chain would lead to inappropriate development projects if extension agents and services and agricultural inputs target men only.

Table 2. Gender disaggregated access to and control over resources and/or benefits of farmers with in a household.

\begin{tabular}{lllll}
\hline & \multicolumn{2}{l}{ Access ((\%) } & \multicolumn{2}{l}{ Control (\%) } \\
\cline { 2 - 5 } & Women & Men & Women & Men \\
\hline Resources/benefits & $\mathbf{3 8 . 9}$ & $\mathbf{6 1 . 1}$ & $\mathbf{3 1}$ & $\mathbf{6 9}$ \\
Land & 50 & 50 & 21.5 & 78.5 \\
Farming equipment & 45 & 55 & 34.5 & 65.5 \\
Home equipment & 70 & 24 & 85 & 15 \\
Labour/purchase of input & 42.3 & 57.7 & 12.9 & 87.1 \\
Cash account in bank & 33.3 & 66.7 & 23 & 77 \\
Benefit from coffee business & 43 & 57 & 20 & 80 \\
Income from employment/trade & 40 & 60 & 36.3 & 63.7 \\
Basic needs & 43.5 & 56.5 & 50 & 50 \\
Entertainment/enjoyment & 38 & 62 & 28.6 & 71.4 \\
Cooperative membership & 0 & 100 & 15 & 85 \\
Idir membership & 50 & 50 & 41.5 & 58.5 \\
Iquib membership & 44 & 56 & 32 & 68 \\
Political/community leadership & 35.8 & 64.2 & 31 & 69 \\
Extension service & 26.6 & 73.4 & 16.6 & 83.4 \\
Technology adoption & 25 & 75 & 21.3 & 78.7 \\
Participate in training/education & 22.5 & 77.5 & 19 & 81 \\
Credit & 46 & 54 & 38 & 62 \\
\hline
\end{tabular}

Source: Author's computation, 2015

\section{Conclusions and Recommendations}

The result of gender analysis revealed that women's and men's role for coffee business in a household was divided by task. Women undertaken mostly the processing, seedling rising and unpaid community activities as an extension of 
their reproductive role and are normally unpaid and carried out in their free time. On the other hand, men tend to be associated more with production and marketing roles than in postharvest handling and processing activities.

However, it is examined that unlike women's overall participation in a value chain was highly acknowledged, they still tend to be confined to a relatively less access to and control over resources and benefits earned from coffee business. Therefore, gender inclusive value chain strategies paying attention on women's empowerment and ensuring gender equality leaving women no worse off must be deigned. The government and concerned bodes in the specific gender departments all over the country should promote the equal and impartial access to some institutional supports like training access, extension services, credit access and experience sharing exposures. Besides, specific policy measures like setting targets or quotas for women in the respect of may be trainings or other advantages and persuading the husbands to send out their respective wife to the community where and when opportunities are coming to the area. These way women could better be empowered and benefited in line with their contribution.

\section{References}

[1] World Bank, 2010. Country Statistics. http://data.worldbank.org/data-catalog.

[2] FAO/WFP, 2008. Special report on crop and food supply assessment mission to Ethiopia, 24 January 2008, FAO/WFP.
[3] Samuel Gebreselassie and Eva Ludi, 2008. Agricultural Commercialization in Coffee Growing Areas of Ethiopia.

[4] Kaplinsky, R. and M. Morris, 2001. A handbook of value chain analysis. Working paper prepared for the IDRC. Institute for Development Studies. Brighton, UK.

[5] Elson, D., 19. Labor markets as gendered institutions: equality, efficiency and empowerment issues. World development, 27 (3), pp. 611-627.

[6] UNIDO, 2009. Agro-value chain analysis and development: a staff working paper, Vienna.

[7] Anjani Kumar A, Harbir Singha, Sant Kumara and Surabhi Mittalb, 2011. Value chains of agricultural commodities and their role in food security and poverty alleviation A Synthesis. Agricultural Economics Research Review. Vol. 24 JanuaryJune 2011. pp 169-181.

[8] Abasanbi, A. A. 2010. Assessment of coffee quality and its related problems in Jimma Zone of Oromia Regional State. MSc thesis in Agriculture (Horticulture). 141p. Jimma (Ethiopia): Jimma University.

[9] ORG, 2003. Gomma district based development program: project document. Oromia Economic Study Project Office. Addis Ababa, Ethiopia.

[10] Jimma Zone Agricultural and Rural Development Office (JZARDO), 2008. Annual Report for year 2007/08, Jimma.

[11] ARDO, 2008. Annual Report of Agriculture and Rural Development Office of Gomma district, for year 2007/2008. Agaro, Gomma.

[12] Cochran, W. G., Sampling Techniques. Second Edition. John Wiley and Sons, Inc. New York. 1953-1963. Library of Congress Catalog Card Number: 63-7553. P206-20]. 